\title{
膝感覚固有感覚測定装置の考案と作成 一測定值の信頼性の検討一 \\ Development of a New Apparatus for Measuring Proprioception of the Knee Joint: Reliability of Measurement Values
}

昇寛1）丸山 仁司 ${ }^{2}$ 高橋 直子1）斉藤 琴子3)

HiROSHI NOBORI, RPT, MA ${ }^{1)}$, Hitoshi MARUYAMA, RPT, Ph.D ${ }^{2)}$, NAOKO TAKAHASHI, RPT ${ }^{1)}$, KотоKO SAITO, RPT, MS $^{3)}$

1) Department of Rehabilitation, Seibo Hospital: 2-5-1 Nakaochiai, Shinjuku-ku, Tokyo 161-0032, Japan. TEL +81 3-3951-1111 2) Department of Physical Therapy, International University of Health and Welfare

3) Department of Physical Therapy, Tokyo Metropolitan Rehabilitation Hospital

Rigakuryoho Kagaku 19(4): 299-303, 2004. Submitted Oct. 23, 2003. Accepted Jun. 28, 2004.

ABSTRACT: The objective of this study was the development of a trial apparatus for measuring knee joint proprioception, the verification of the reliability of its measurements, and the appraisal of its potential for clinical use. Two examiners measured knee joint threshold value and position sense of the 20 knees of 10 healthy females. The examination of position sense was from 90 degrees extension at an angular velocity of 0.1 degree/sec, and at 85,75 and 65 degrees the measured angle difference was measured. Between examiners the reliability of the threshold value was ICC $(3,1)=0.73$, and the reliability of position sense was ICC $(3,1)=0.86$, showing a high reliability of measurement. The results suggest that the knee joint proprioception measurement apparatus which we designed and built, would be valid for objective assessment.

Key words: knee joint, proprioception measurement apparatus, reliability

要旨: 本研究の目的は, 膝関節固有感覚測定装置を試作して, 本装置の測定值の信頼性を検証し, 臨床応用への可能 性を明らかにすることである。健常女性10名の20膝を対象として，2名の検者によって膝関節閾值と位置覚を測定し た。閾值検査は膝関節屈曲 $60^{\circ}$ からの伸展運動（角速度 $0.1^{\circ} / \mathrm{s} ）$ の感知までの時間を測定した。位置覚検查は9 $90^{\circ}$ か ら伸展 (角速度 $1^{\circ} / \mathrm{s}$ ) し， $85^{\circ} 75^{\circ} 65^{\circ}$ での測定誤差角度を測定した。測定值の信頼性は，検者間信頼性において

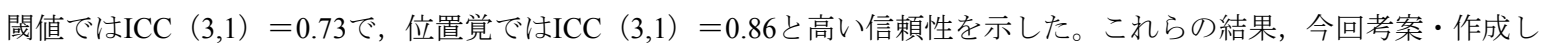
た膝関節固有感覚測定装置は, 客観的評価に有効な測定器であると示唆された。

キーワード：膝関節，固有感覚測定装置，信頼性

1) 聖母病院 リハビリテーション室 : 東京都新宿区中落合2-5-1（テ 161-0032）TEL 03-3951-1111

2) 国際医療福祉大学 理学療法学科

3) 東京都リハビリテーション病院 理学療法科

\section{受付日 2003年10月23日 受理日 2004年6月28日}




\section{I.はじめに}

整形外科領域の疼痛性疾患においては，変形性膝関節 症や慢性関節リウマチによる膝関節疾患が多くみられ る。さらに，症状の進行により人工膝関節全置換術（以 下，TKAという）の適応となる症例も多い。

膝関節疾患患者やTKA術後患者等の正常歩行や，転倒 防止などを考慮する時, 関節可動域の獲得や筋力の獲得 と同様に関節固有感覚の獲得も重要なリハビリテーショ ン目的の1つと考えられる。正常歩行の遂行, 転倒防止に は適度な筋緊張とバランス能力が必要である。筋肉の緊 張にはまず中枢神経が重要な役割を果たし，ついで前庭 機能や視床機能が関与寸る。さらに，関節の位置や運動 方向を瞬時に感知し，それをフィードバック寸る感覚が 重要となる。これが関節固有感覚といえる。

閾值検查や位置覚検查などの関節固有感覚検查は, 客 観的に評価し得る検査である。“僅かな関節の動き”の認 知度を調べる閾值検查や関節角度の認知度を調べる位置 覚検査は進行した膝関節疾患患者やTKA等の術後患者の 理学療法評価においては, 特に重要な評価項目であると 考えられる。

しかし，現在一般的に行われている定量性の高い関節 固有感覚検查の測定装置としてはKIN/COMやBIODEXの ように非常に高価な検査装置であり，また測定に関する 操作・設定にも煩雑な淮備を要することが多い。関節固 有感覚検查は, 関節可動域検査や徒手筋力検查などと同
様に実用的検査として日々行われることが望ましいが， このような理由で一般病院などの臨床の現場での定量的 測定器の設置は少数で，実用されることが少ないのが現 状と思われる。

今回，このような実情を踏まえ，臨床の現場において 簡易な操作・設定で測定可能な検查装置を整備すること を目的として，独自に膝関節固有感覚測定装置を考案 • 作成した。さらに当装置で測定した膝関節固有感覚の測 定值の信頼性についても検討した。

\section{II. 膝関節固有感覚測定装置について}

関節固有感覚検查の実施については一部の研究施設や 大学病院などを除いて多くの一般病院などの臨床の現場 では装置などを用いない方法での実施が多いと思われ る。例えば，検者が被検者に閉眼させ四肢を受動的に一 定の位置にさせ，被検者にその位置を言ってもらうか反 対側の上下肢でまねをさせる方法1)等で行われてきた。既 存の定量的な関節固有感覚測定装置は前述のKIN/COM やBIODEXが存在する。肢を固定するアームが動力を有 し等速度で回転する仕組みで，その回転角度や回転速度 をパソコンに取り込みデータをデジタル変換し数值化さ れるという装置が現行では少数施設で用いられている。

今回，考案・作成した膝関節固有感覚測定装置の全体 構造を図1に示す。構成は次の通りである。デジタル角度 表示測定装置には「膝関節専用筋力訓練・測定システム

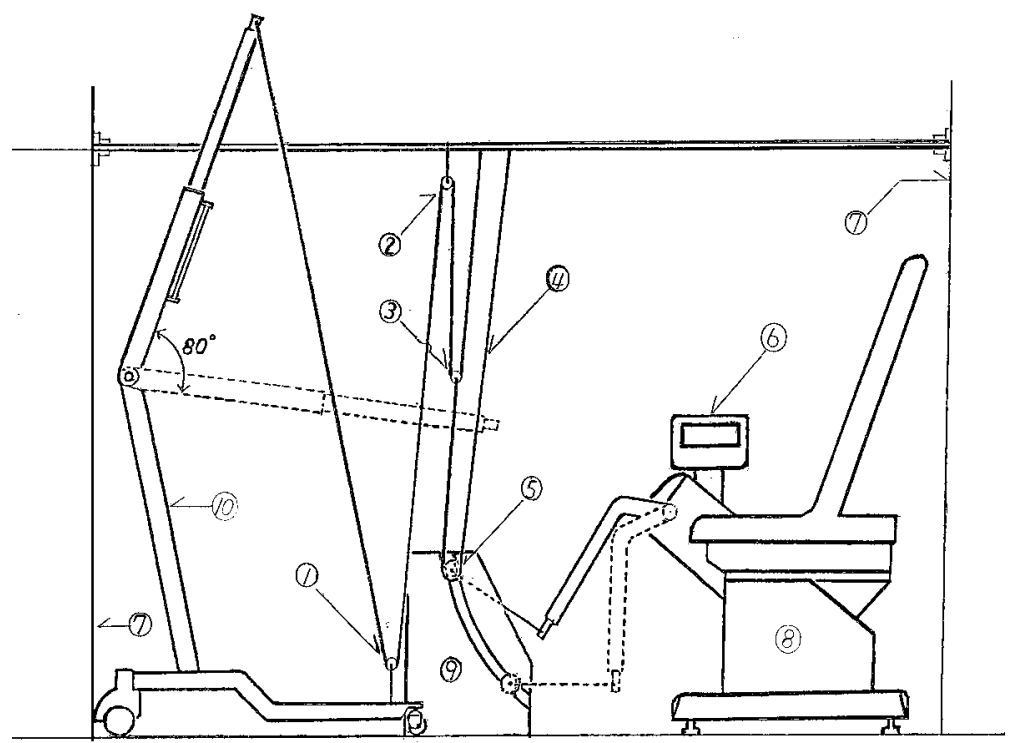

(1)固定滑車

(2)固定滑車

(3) 可動滑車

(4) 直径 $2 \mathrm{~mm}$ ワイアー

(5) 三連可動滑車

(6) 膝関節角度デジタル表示計

(7) 壁面

(8) 膝関節専用筋力訓練測定システム (9) 膝関節固有感覚測定装置本体 (10) 電動リフト

図1 股関節固有感覚測定装置全体図 
COMBIT CB-2」(ミナト医科学社製）を使用した。牽引 動力源として「電動リフトKQ-740V-0092G」(パラマウン トベッド社製), スピード調節変圧計には「LUCON TCM400B」(トヨスター社製)を使用した。また, アーム牽引 には直径 $2 \mathrm{~mm}$ の鋼線ワイアーを使用した。装置本体は, 三連動滑車を等速度で接線上を牽引し，案内溝に沿って 走行・移動・停止することを可能とするよう設計した。 本体の案内溝を走行する三連可動滑車が 1 個, 可動滑車が 1個, 固定滑車が2個で電動リフトの動力によりCOMBIT$\mathrm{CB} 2$ の下腿取り付けアームを牽引と下降する構造であ る。検查可能角度は膝関節屈曲 $95^{\circ} \sim 55^{\circ}$ の範囲とし, 角速度は, $0.1^{\circ} / \mathrm{s} \sim 1^{\circ} / \mathrm{s}$ の範囲で調節可能なものとした。 アームの角速度の一定性を確認する装置として「パネル PCL ; 光センサー型タイマー」(キーエンス社製)を電動 リフトのスイッチに取り付けて用いた。装置本体の素材 は硬性アクリル製材を使用し，各々の装置は，全て取り 外し可能なものとした。

なお, 装置本体については現在, 特許出願中である。

\section{III. 対象と方法}

1. 被検者について

被検者は若年健常女性10名であり, 20膝を対象とした。 平均年齢は $19.5 \pm 0.5$ 歳, 平均身長は $160.7 \pm 3.9 \mathrm{~cm}$, 平均 体重は52.2 $\pm 3.3 \mathrm{~kg}$ であった。

被検者全員に事前に検查の内容を説明し検査について の同意を得た。

\section{2. 閾值の測定方法}

被検者はCOMBIT CB-2に端座位となり, 膝関節屈曲 $60^{\circ}$ にアームを設定した。視覚刺激・聴覚刺激を除き, 屈曲 $60^{\circ}$ の位置より他動的に角速度 $0.1^{\circ} / \mathrm{s}$ で伸展方向に 率引し, 被検者は僅かな動きでも感知したら, その地点 で検者に口頭で知らせ，検者はその感知までの時間を測 定した。検查は両側に対して実施した。

被検者 10 名 20 膝に対して, 1 回の検查で3回測定し, 感 知までの時間（秒）の平均値を算出し, 解析した。

\section{3. 位置覚の測定方法}

被検者はCOMBIT CB-2に端座位となり, 膝関節下垂位 (屈曲 $90^{\circ}$ ) にアームを設定した。視覚刺激・聴覚刺激を 除き, 屈曲 $90^{\circ}$ の位置より他動的に角速度 $1^{\circ} / \mathrm{s}$ で伸展方 向に牽引し, 検查角度を1回目が屈曲 $85^{\circ}, 2$ 回目が屈曲 $75^{\circ}, 3$ 回目が $65^{\circ}$ とした。各回 5 秒間その位置で静止し,
その位置を記憶するように指示した。指示の後, $90^{\circ} に$ 戻し, 再び角速度 $1^{\circ} / \mathrm{s}$ で伸展方向に牽引し, 被検者は先 に記憶した位置に到達したと感知した地点で検者に口頭 で知らせ，検者はその角度の誤差を測定した。検查は左 右両側に対して実施した。予備練習を2回行い, 引き続き 本検查を実施した。

被検者 10 名 20 膝に対して1回の検查で 3 地点 (屈曲 $85^{\circ}$, $75^{\circ} ， 65^{\circ}$ ) について検查し, 角度の誤差の平均值を算 出し, 解析した。

尚, 学習効果の排除と検者間の信頼性を調べる目的で, 両検查とも検者 $\mathrm{A} ， \mathrm{~B}$ にって 7 日間あけて実施した。

\section{4. 統計処理}

膝関節固有感覚（膝関節閾值・位置覚）の検者内・検 者間信頼性については級内相関係数によって検討した。 統計ソフトは「SPSS 10.0J for windows」を使用した。

\section{IV. 結 果}

1. 閾値の検查結果と信頼性について（表1）

被検者 10 名 20 膝に対して行った閾值検査における感知 までの時間の平均は, 検者Aによる検查では7.3 11.7 秒 で，検者Bによる検查では $6.7 \pm 1.7$ 秒となった。

検者内信頼性係数は検者 $\mathrm{A}$ の測定においては, ICC $(1,1)=0.87$, 検者Bの測定においては, ICC $(1,1)=0.88$ であった。

また, 検者間信頼性係数はICC $(3,1)=0.73$ となり, 高 い信頼性を示した。

\section{2. 位置覚の検査結果と信頼性について}

被検者 10 名 20 膝に対していった位置覚検査における誤 差角度の平均は, 検者 $\mathrm{A}$ にる検査では, $1.9 \pm 1.2^{\circ}$ で, 検者Bによる検查では， $1.7 \pm 1.2^{\circ}$ となった。

検者内信頼性係数は検者 $\mathrm{A}$ の測定においてICC $(1,1)=$

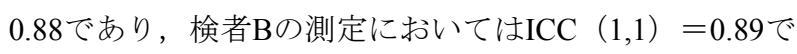
あった。

また, 検者間信頼性係数はICC $(3,1)=0.86$ で, 位置 覚においても高い信頼性を示した。

また，10名20膝における閾值と位置覚の関連について は, 検者Aによる閾値検查の平均值と位置覚検査の平均 值との関連は $\mathrm{r}=0.89(\mathrm{p}<0.01)$, 検者 $\mathrm{B}$ による閾值検査の平 均值と位置鸴検查の平均値との関連は $\mathrm{r}=0.69(\mathrm{p}<0.01)$ と いずれも有意な相関を示した。 
表1 膝関節固有感覚検査結果

a. 検者内信頼性

検者 $\mathrm{A} \quad(\mathrm{n}=20)$

\begin{tabular}{lcccc}
\hline & $1^{\text {st }}$ & $2^{\text {nd }}$ & $3^{\text {rd }}$ & $\operatorname{ICC}(1,1)$ \\
\hline 閾值 & $7.7 \pm 1.7$ & $7.4 \pm 1.8$ & $6.9 \pm 1.5$ & 0.87 \\
位置覚 & $2.3 \pm 1.2$ & $2.0 \pm 1.2$ & $1.7 \pm 1.1$ & 0.88 \\
\hline
\end{tabular}

検者 B $\quad(n=20)$

\begin{tabular}{lcccc}
\hline & $1^{\text {st }}$ & $2^{\text {nd }}$ & $3^{\text {rd }}$ & $\operatorname{ICC}(1,1)$ \\
\hline 閾值 & $7.0 \pm 1.9$ & $6.5 \pm 2.1$ & $6.4 \pm 1.9$ & 0.88 \\
位置覚 & $1.8 \pm 1.5$ & $1.8 \pm 1.3$ & $1.5 \pm 1.2$ & 0.89 \\
\hline
\end{tabular}

(注) 閾值の単位は $\left(^{\prime \prime}\right)$, 位置覚の単位は $\left(^{\circ}\right)$. 位置覚の 1st，2nd，3rd はそれぞれ $85^{\circ} ， 75^{\circ} ， 65^{\circ}$ での誤差.

\section{V. 考 察}

1. 膝関節固有感覚測定装置についての検討

膝関節固有感覚測定装置については, 現在KIN/COM, BIODEX等が開発され, 多くの臨床家や研究者らによっ て用いられている。また, 先行研究においては, Remedios ら2)が電気角度計を両膝に装着して測定する方法で行っ ている。Lattanzioら ${ }^{3)}$ はPenny \& Gilesの電気角度計を用い て静的膝角度の再現性を調べた。Barettら ${ }^{4)}$ は模型膝で設 定角度の再現性検査装置として工夫した。

今回, 筆者らはSkinner $ら^{5)}$, Lephart $^{6)}$, Corrigan $ら^{7)} の$ 用いた接線牽引モデルを参考に, 独自の構造・システム を考案し, 装置を作成した。膝関節固有感覚測定装置は, いわゆる閾值と位置覚を測定可能なものとして設計し た。

本装置の特徴の第 1 は, アームの角速度を一定にする ための “接線での牽引”を可能とする孤と滑車の構造で ある。前述のSkinner $5^{5)}$, Lephart $5^{6)}$, Corrigan $ら^{7)}$ の研究 において接線で牽引することは述べられているが, 動力 と構造物の連結方法など全体のシステムについては触れ られていない。そこで, 我々は孤の形状の案内溝をつく り, その中を三連滑車が走行する構造を独自に考案して 作成し“接線での牽引”を実現した。

特徵の第 2 は, 角速度確認のための「光センサー型タイ マー」による “時間と回転角度の連動システム”である。 “接線での牽引”によってアームの角速度を一定にするこ とと同時に“時間と回転角度の連動システム”により， b. 検者間信頼性

閾值検査

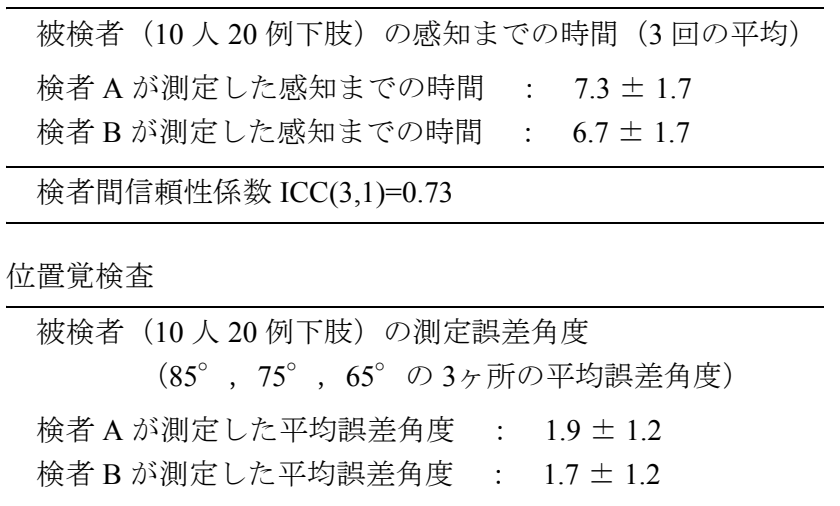

検者間信頼性係数 $\operatorname{ICC}(3,1)=0.86$

（注）閾值の単位は $(")$, 位置覚の単位は $\left(^{\circ}\right)$.

簡便な方法で角速度の設定と変更を可能とした。

2. 膝関節固有感覚検査の測定值と信頼性の検討 今回，考案・作成した装置の測定值と信頼性を確認す ることを目的として, 若年健常女性10名20膝を対象に膝 関節固有感覚（閾值・位置覚）の検査を実施した。

まず，閾值検査の測定值については感知までの時間の 平均值が 6 7 秒程度の範囲であった。先行研究では, Skinner $5^{5}$ )が膝関節屈曲 $60^{\circ}$ からの動きの感知を測定す る実験を行っており, 感知までの時間の平均值が7秒程度 であったと報告している。筆者らの行った閾值検査での 感知までの時間の平均值とほぼ一致した。

位置覚検査の測定值については, 先行研究における多 くが測定誤差角度で検討されている。膝関節位置覚測定 はSkinnerやBarrackら 5)によって多く報告されており，測 定誤差角度は $2^{\circ} \sim 5^{\circ}$ 程度としている。筆者らの行った 位置覚検査では，検者 $\mathrm{A}, \mathrm{B}$ の測定した測定誤差角度の平 均值が $1.7^{\circ} \sim 1.9^{\circ}$ の範囲であり, 先行研究と比較して優 良な測定值を得た。

以上のように優良な測定值を得ることができたのは， 両検査で実施した “遅い角速度”に起因していると考え られる。先行研究の多くでは, 閾值検査, 位置覚検査と もその角速度は検者によって異なっているのが現状であ る。Skinner $5^{5}$ は閾值検査を角速度 $0.5^{\circ} / \mathrm{s}$ で, 位置覚検査 を角速度 $10^{\circ} / \mathrm{s}$ で実施している。Marks ${ }^{8)}$ も位置覚検査を $10^{\circ} / \mathrm{s}$ で実施している。高取ら䍃の研究では「角速度の増 加に伴い認知角度も増大寸る」とし, 原因として被検者 
が実際に運動認知してから口頭で表出するまでに時間的 遅延が生じ, それが角速度の増加とともに認知角度の増 加として表れたものと考えた。筀紡錘の運動速度の認知 についての研究でWeilerら ${ }^{10)}$ は, 「筋紡錘は運動探知を請 け負う受容器で $0.01^{\circ} / \mathrm{s}$ の動きを理論上感知できる。」と 報告している。いかに迅速な運動認知ができたとしても 反応表示までの時間が小さくなければ精度に欠ける。換 言すれば, 運動認知と反応表示までの時間が小さいほど 測定值の精度は高いといえる。閾值検查においても位置 覚検査においても, より遅い速度での検査が “運動認知” と “反応表示” 間のTime lagに伴う角度誤差を小さく出来 ると考えられる。

これらの知見を踏まえ, 今回考案・作成した本装置の アームの回転角速度は最小 $0.1^{\circ} / \mathrm{s}$ を実現させた。このこ とは, より高い精度の関節固有感覚検査の不可欠の条件 と考え, 装置の考案・作成にあたり最重要課題とした。

次に, 信頼性については膝関節固有感覚（閾値・位置 覚）における2名の検者 $\mathrm{A}, \mathrm{B}$ の検者内信頼性係数, 及び 検者間信頼性係数を調べた。検者内信頼性ではICC $(1,1)$ $=0.87 \sim 0.89$, 検者間信頼性ではICC $(3,1)=0.73 \sim 0.86$ と 閾值検査, 位置覚検査においてともに高い信頼性を示し た。

測定值の信頼性を調査した研究では, Latteanzioら³)の 報告がある。TKAを施行したグループ20膝とTKAを施行 しないグループ20膝の位置覚再現性検査を実施したとこ ろ, それぞれの信頼性係数ICCは0.92，0.60であったと報 告している。また, Kieferら ${ }^{11}$ は23人の健常男性と17名の 健常女性を被検者として $15^{\circ} ， 30^{\circ} ， 45^{\circ} ， 60^{\circ}$ での位 置覚再現検查を行い, 2 回行った検査の信頼性係数が ICCs<0.67であったと報告している。

筆者らの得た信頼性係数をLandis ${ }^{12)}$ の判定基準によ り照らしても, substantial $(0.61 \sim 0.80) \sim$ almost perfect $(0.81$ 〜1.00）の範囲で高い信頼性といえる。

高い信頼性を得られたことは, 今回考案・作成した装 置での測定值に客観性があることを示すもので, 「操作的
に定義された手続きに従って測定を行えば，誰でも同じ ように測ることができる13)」ことを示唆するものである。 これらの高い信頼性は本装置の有用性を裏付けるもの で, 臨床評価に有効な測定器であると考えられる。

\section{引用文献}

1) 田崎義昭, 斎藤佳雄 : ベッドサイドの神経の診方. 南山堂, 東京, 2000, p95.

2) Remedios L, Morris M, Bendrups A: Reduced static proprioception of the knee joint following anterior cruciate ligament reconstruction. Physiotherapy Canada, 1998, Fall: 299-308.

3) Lattanzio PJ, Chess DG, MacDermid JC: Effect of the posterior cruciate ligament in knee-joint proprioception in total knee arthroplasty. J Arthroplasty, 1998, 13(5): 580-585.

4) Barett DS, Cobb AG, Bentley G: Joint proprioception in normal, osteoarthristic and replaced knees. J Bone Joint Surg, 1991, 73B: 53-56.

5) Skinner HB, Barrack RL, Cook SD, et al.: Joint position sense in total knee arthroplasty. J Orthop Res, 1984, 1: 276-283.

6) Simmons S, Lephart S, Rubash H, et al.: Proprioception following total knee arthroplasty with and without the posterior cruciate ligament. J Arthroplasty, 1996, 11(7): 763-768.

7) Corrigan JP, Cashman WF, Brady MP: Proprioception in the cruciate deficient knee. J Bone Joint Surgery, 1992, 74B: 247-250.

8) Marks R: Within-subject variability associated with repeated measurements of knee position sense in an osteoarthritic sample:Implications for researchers and clinicians. Physiother Canada, 2001, Fall: 276-281.

9) 高取克彦, 小室 透, 山下堅志・他 : 肩関節運動覚測定にお ける検討. 第37回近畿理学療法士学会誌, 1997 : 72-73.

10) Weiler HT, Pap G, Awiszus F: The role of joint afferents in sensory processing in osteoarthritic knees. Rheumatology, 2000, 39: 850-856.

11) Kiefer G, Forwell L, Kramer J, et al.: Comparison of sitting and standing protocols for testing knee proprioception. Physiotherapy Canada, 1998, Winter: 30-34.

12) Landis JR, Koch GG: The measurement of observer agreement for categorical data. Biometrics, 1977, 33: 159-174.

13) 谷 浩明: 評価の信頼性. 理学療法科学, 1997, 12(3): 113-120. 